\title{
Thymoquinone Improves Anti-Diabetic Activity of Metformin in Streptozotocin-Induced Diabetic Male Rats
}

\author{
Bishoy El-Aarag ${ }^{1^{\star}}$, Wesam Hussein $^{2}$, Wafaa Ibrahim $^{3}$ and Magdy Zahran ${ }^{4}$ \\ ${ }^{1}$ Biochemistry Division, Chemistry Department, Faculty of Science, Menoufia University, Shebin El-Koom, Egypt \\ ${ }^{2}$ Biochemistry Section, Department of Chemistry, Faculty of Science, Tanta University, Egypt \\ ${ }^{3}$ Department of medical Biochemistry, Faculty of Medicine, Tanta University, Egypt \\ ${ }^{4}$ Chemistry Department, Faculty of Science, Menoufia University, Shebin El-Koom, Egypt
}

"Corresponding author: Bishoy El-Aarag, Biochemistry Division, Chemistry Department, Faculty of Science, Menoufia University, Shebin El-Koom, Egypt, Tel: +20-1273672673; E-mail: bishoy.yousef@gmail.com

Received date: November 30, 2017; Accepted date: December 26, 2017; Published date: December 28, 2017

Copyright: ( 2017 El-Aarag B, et al. This is an open-access article distributed under the terms of the Creative Commons Attribution License, which permits unrestricted use, distribution, and reproduction in any medium, provided the original author and source are credited.

\begin{abstract}
The current study aimed to investigate the effects of thymoquinone (TQ) to enhance the anti-diabetic effect of metformin (MET) in streptozotocin-induced diabetes in male rats. The mutual effect of TQ and MET on biochemical parameters such as glucose, cholesterol, triglycerides, and glycated hemoglobin was estimated. Also, their combined influence on malonaldehyde (MDA) and total anti-oxidant capacity (TAC) in liver and pancreas tissues homogenates were assessed. Furthermore, their synergistic effects on the expression of mRNA encoding glucose transporter-2 (Glut-2) were evaluated. Moreover, insulin receptor labeling index percentage in liver tissues was estimated. Results revealed that the alteration in biochemical levels due to streptozotocin action was corrected and restored by TQ plus MET with more pronounced effect than MET alone. Also, in liver homogenate both TQ and MET decreased the elevated MDA level to 8.82 and augmented the TAC level to 2.71, compared to their values in MET group 14.64 and 1.19, respectively. Furthermore, TQ plus MET up-regulated the expression level of Glut-2 by $88.2 \%$, compared to $80 \%$ in MET group. Taken together, our study revealed that TQ via its anti-oxidant properties is a useful combination therapeutic agent to enhance the anti-diabetic activity of MET in STZ-induced diabetic rats.
\end{abstract}

Keywords: Diabetes mellitus; Thymoquinone; Metformin; Streptozotocin; Glucose transport-2; Insulin receptor

\section{Introduction}

Diabetes mellitus (DM) is characterized by chronic hyperglycemia with metabolism disorder of carbohydrate, fat and protein resulting from failures in insulin secretion, insulin impact, or together [1]. Mainly, there are two types of diabetes mellitus; type 1 and type 2 [2]. Type 1 is a defect in the immune system resulting in a loss of selftolerance and inflammatory destruction of the insulin producing $\beta$ cells [3,4]. Type 2 is the most common type and involving insulin resistance and deficiency [5]. Type 2 diabetes is a global epidemic with an estimated worldwide prevalence of 415 million people in 2015, which is predicted to increase to 642 million people by 2040 [6]. The majority of this diabetic population gets from developing countries [7].

The very considerable health, social and economic burdens caused by DM $[8,9]$ present a major challenge to health-care systems around the world. To lower the risk of diabetic complications effective management of continued glycemic control was required [10]. The usage of anti-diabetic drugs mainly depends on type of diabetes. Type 2 -antidiabetic drugs fundamentally possess activities to lower blood glucose by increasing the quantity of pancreatic insulin secretion, increase sensitivity of target organs to insulin or decrease the absorbed rate of glucose from the gastrointestinal tract [11].

Metformin (MET), an oral hypoglycemic drug related to biguanides, is commonly used for the management of type 2 diabetes. MET diminishes fasting glucose concentration by decreasing hepatic glucose production level via gluconeogenesis and glycogenolysis [12,13].

One of the medicinal plants with anti-hyperglycemia and antihyperlipidemia effects is Nigella sativa (NS) $[14,15]$ and most of its therapeutic properties are due to the presence of thymoquinone (TQ) (28-57\%) [16-18]. Moreover, its hepatoprotective, anti-inflammatory, anti-oxidant, cytotoxic, anti-cancer, hypoglycemic $[19,20]$ and radical scavenging activities [21] has been reported.

Consequently, the aim of the current study was to investigate the combined effect of TQ and MET on biochemical profile, lipid peroxidation, total anti-oxidant capacity (TAC), and glucose transporter-2 (Glut-2) in streptozotocin (STZ) induced DM in male rats.

\section{Materials and Methods}

\section{Animals}

Fifty white male albino rats (Rattus norvegicus) (aged 6-7 weeks and weighing 120-130 g) were purchased from the laboratory animal house of Tanta University, Egypt and housed in well-ventilated plastic cages. The animals were housed under standardized environmental conditions. Animals received food and water ad libitum. Rats were maintained on a 12:12 h light/dark cycle and acclimated for 1 week before beginning of the experiment. Rats were maintained as performed by national guidelines and protocols, approved by the University Scientific Research Ethics Committee. 


\section{Thymoquinone (TQ)}

TQ was obtained from Sigma Chemical Co. (St. Louis, MO). It was dissolved firstly in dimethyl sulfoxide (DMSO), followed by saline addition (the final concentration of DMSO was less than $0.5 \%$ ). The solution was administered orally through stomach tube at a dose of 50 $\mathrm{mg} / \mathrm{kg}$ body weight once daily, for 7 successive weeks.

\section{Induction of diabetes}

Diabetes was induced in male rats by administering intraperitoneally injection of a freshly prepared solution of STZ (Sigma) $(65 \mathrm{mg} / \mathrm{kg}$ body weight) in $0.1 \mathrm{M}$ citrate buffer $(\mathrm{pH} 4.5)$ to the overnight fasted rats. After 3 days, fasting blood glucose levels were measured and rats with glucose concentration higher than $200 \mathrm{mg} / \mathrm{dl}$ were considered diabetic and used in the study [22].

\section{Experimental design}

A total of 50 rats included 10 normal and 40 STZ-diabetic were used in the experiment. Rats were divided into 5 groups each consisting 10 rats.

Group 1: Control group: rats were orally taken citrate buffer.

Group 2: Diabetic group: diabetic rats were orally given saline containing DMSO, daily for 7 successive weeks.

Group 3: TQ group: diabetic rats orally treated with TQ (80 mg/kg), daily for 7 successive weeks.

Group 4: MET group: diabetic rats orally treated with MET (500 $\mathrm{mg} / \mathrm{kg}$ ) (sigma), daily for 7 successive weeks.

Group 5: TQ + MET group: diabetic rats orally treated with TQ (80 $\mathrm{mg} / \mathrm{kg}$ ) + MET (500 mg/kg) (orally), daily for 7 successive weeks.

Treatment was continued for 7 weeks. The initial and final (before sacrificing) body weights of all the experimental animals from each group were measured using a digital balance to calculate body weight gain (BWG). At the end of the treatment period, the rats were fasted overnight, anaesthetized with diethyl ether and the liver and pancreas of each rat was dissected out.

\section{Sampling and analysis}

Blood samples were collected into a tube containing ethylenediaminetetraacetic acid (EDTA) (Sigma) for measurement of glycated hemoglobin (HbA1c) and other samples were allowed to coagulate and then centrifuged at $3000 \times \mathrm{g}$ for $10 \mathrm{~min}$ and sera were collected for biochemical analysis. Liver and pancreas tissues were washed in cold saline. Part of the liver and pancreas was homogenized in cold PBS, centrifuged at $3000 \times \mathrm{g}$ for $10 \mathrm{~min}$ at $4^{\circ} \mathrm{C}$ and the supernatant was stored at $-20^{\circ} \mathrm{C}$. The other specimen was fixed with $10 \%$ formalin solution for immunohistochemistry examinations.

\section{Biochemical assays}

The biochemical alterations in the serum included glucose [23], cholesterol [24], and triglycerides [25] were assessed as well as HbAlc was estimated in the blood as previously described [26].

\section{Estimation of lipid peroxidation}

Malondialdehyde (MDA) level is an index of lipid peroxidation. The degree of lipid peroxidation was determined by measuring thiobarbituric acid reactive substances (TBARS) in the tissue supernatant [27]. Briefly, liver and pancreas tissues homogenates were centrifuged at $3000 \mathrm{rpm}$ for $15 \mathrm{~min}$ and supernatants were collected and used for the estimation of TBARS as MDA equivalents. The absorbance was measured spectrophotometrically at $532 \mathrm{~nm}$ and the concentrations were expressed as nmol TBARS/g wet tissue.

\section{Estimation of total anti-oxidant capacity (TAC)}

TAC in liver and pancreas tissues homogenates was estimated by ferric reducing anti-oxidant power (FRAP) assay [28]. Briefly, ferric iron $\left(\mathrm{Fe}^{3+}\right)$ is initially reduced by electron-donating anti-oxidants present within the sample to its ferrous form $\left(\mathrm{Fe}^{2+}\right)$. The iron complex develops a dark blue color product upon reduction which can be measured at $593 \mathrm{~nm}$. Samples can be related to the iron standard for determining anti-oxidant potential.

\section{qRT-PCR assay}

Total RNA was isolated from $30 \mathrm{mg}$ of liver tissues using an RNA extraction kit (easy-REDTM, iNtRON Biotechnology, \#17063, South Korea) according to the supplier's protocol. Synthesis of first strand complementary DNA (cDNA) was performed using an oligo-dT primer and superscript reverse transcriptase using reverse transcription kits (Thermo Scientific, Fermentas, \# EP0451)). qRT-PCR for Glut-2 and $\beta$-actin was performed using the SYBR green method with a StepOnePlus real time thermal cycler (Applied Biosystems, Life technology, USA). The primer sequences used for PCR were as follows: Glut-2, forward TAGTCAGATTGCTGGCCTCAGCTT, reverse TTGCCCTGACTTCCTCTTCCAACT; $\beta$-actin, forward AAGTCCСТCACССТCССAAAAG, reverse AAGCAATGCTGTCACCTTCCC. Cycling conditions for amplification of Glut- 2 and $\beta$-actin were as follows: $95^{\circ} \mathrm{C}$ for $10 \mathrm{~min}$, followed by 40 cycles of denaturation at $95^{\circ} \mathrm{C}$ for $15 \mathrm{~s}$, annealing at $58^{\circ} \mathrm{C}$ for $30 \mathrm{~s}$, and extension at $72^{\circ} \mathrm{C}$ for $30 \mathrm{~s}$. The relative gene expression levels were calculated as previously described [29].

\section{Immunohistochemical examination}

Liver slides of all experimental groups were deparaffinized with xylene and dehydrated in a graded ethanol to distilled water concentration series. Antigen retrieval was performed by insertion the slides in $10 \mathrm{mM}$ citrate buffer $(\mathrm{pH} 3.0$ ), heating all in a microwave oven for $20 \mathrm{~min}$, and allowing them to cool to room temperature (RT). After the slides were rinsed once with PBS, the endogenous peroxidase activity was blocked by incubating the slides in blocking solution (3\% $\mathrm{H}_{2} \mathrm{O}_{2}$ in PBS) for 30 min followed by rinsing three times with PBS. The primary antibody, anti-insulin receptor $\operatorname{IgG} 1 / \mathrm{K}$ (thermo fisher scientific, UK), was applied to the slides. All slides were incubated overnight with the primary antibody at RT, washed by PBS then incubated with secondary antibody for $15 \mathrm{~min}$ followed by washing with PBS. Bound antibody was detected using a modified labeled avidin-biotin reagent for $20 \mathrm{~min}$ then washing in PBS. Diaminobenzidine $(0.1 \%)$ was used for $5 \mathrm{~min}$ as a chromogen. Slides were read blindly under a light microscope at $\times 400$ magnification. Over 1,000 cells from at least 5 different fields were counted. Insulin receptor labeling index percentage was calculated as follows: number of positive cells $\div$ total cells counted $\times 100$ [30]. 


\section{Statistical analysis}

Data were expressed as mean \pm standard deviation. Statistical analyses were performed using one-way analysis of variance (ANOVA) to assess significant differences among treatment groups. $\mathrm{P}$ value less than 0.05 was accepted as significant.

\section{Results}

\section{Effect of TQ and MET on the level of glucose, cholesterol, and triglycerides}

Results in Figure 1 showed that the mean values of fasting blood glucose were significantly $(\mathrm{P}<0.001)$ increased in rats of diabetic group, compared with those of the normal control. But, treating diabetic rats with both TQ and MET for 7 weeks significantly $(\mathrm{P}<0.001)$ reduced and normalized the elevation of glucose level. Furthermore, the level of cholesterol in diabetic rats was significantly $(\mathrm{P}<0.001)$ increased compared with normal ones. Treating the diabetic rats with either TQ, MET or both significantly $(\mathrm{P}<0.001)$ decreased the level of serum cholesterol, although being higher than that of the non-diabetic control group. Moreover, triglycerides level was significantly $(\mathrm{P}<0.001)$ elevated in diabetic rats compared with rats in normal control group. The elevation of triglycerides level was significantly $(\mathrm{P}<0.01)$ or $(\mathrm{P}<0.05)$ reduced after the treatment with either TQ or MET, compared with diabetic group. Interestingly, triglycerides level was corrected to the normal values after the treating with both TQ and MET together.

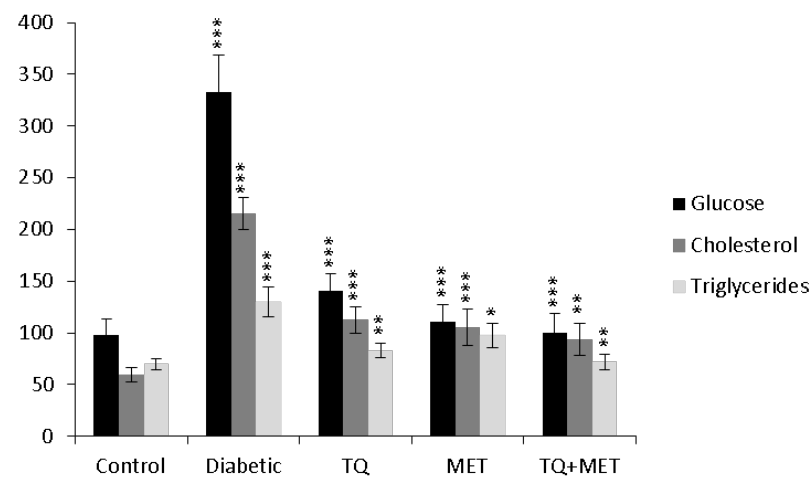

Figure 1: Effect of TQ and/or MET on glucose, cholesterol, and triglycerides level. Data are presented as mean \pm standard deviation. Significantly $\left({ }^{*} \mathrm{P}<0.05,{ }^{*} \mathrm{P}<0.01,{ }^{* *} \mathrm{P}<0.001\right)$ different from the diabetic control. TQ: thymoquinone; MET: metformin.

\section{Effect of TQ and MET on body weight gain}

As shown in Figure 2, the administration of STZ resulted in significant $(\mathrm{p}<0.001)$ loss in BWG as compared to normal control group. The treatment of diabetic rats with either TQ or MET significantly $(\mathrm{p}<0.001)$ declined the loss in the BWG. However, the treatment with both TQ plus MET for 7 weeks showed a significant improvement in BWG rather than that of either TQ or MET group, individually.

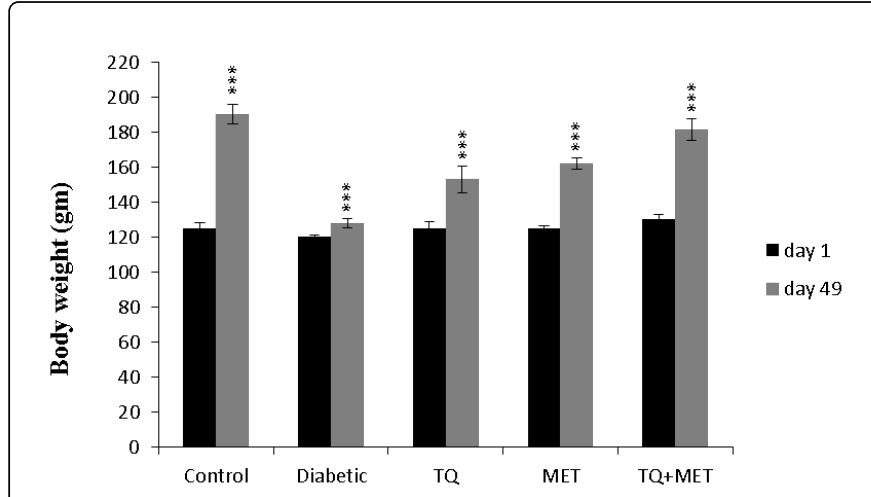

Figure 2: Effect of TQ and/or MET on body weight gain in male rats. Data are presented as mean \pm standard deviation. Body weights were measured at day 1 and 49 by using digital balance and expressed by (gm). ${ }^{* *} \mathrm{p}<0.001$ versus diabetic control.

\section{Effect of TQ and MET on HbAlc level}

Estimation of HbAlc has been found to be particularly useful in monitoring the effectiveness of therapy in diabetes [31]. Thus, the effect of TQ and MET in diabetic rats was measured. As displayed in Figure 3, positive control group showed significant $(\mathrm{P}<0.001)$ increase in HbAlc level as a result of STZ-induced diabetes, compared with that of the non-diabetic group. Treating diabetic rats with TQ or MET significantly $(\mathrm{P}<0.001)$ decreased the level of $\mathrm{HbA1c}$, the recorded level is $6.9 \%$ and $6.63 \%$, respectively. Meanwhile, the combined effect of TQ plus MET was reduced the HbAlc level to $6.08 \%$.

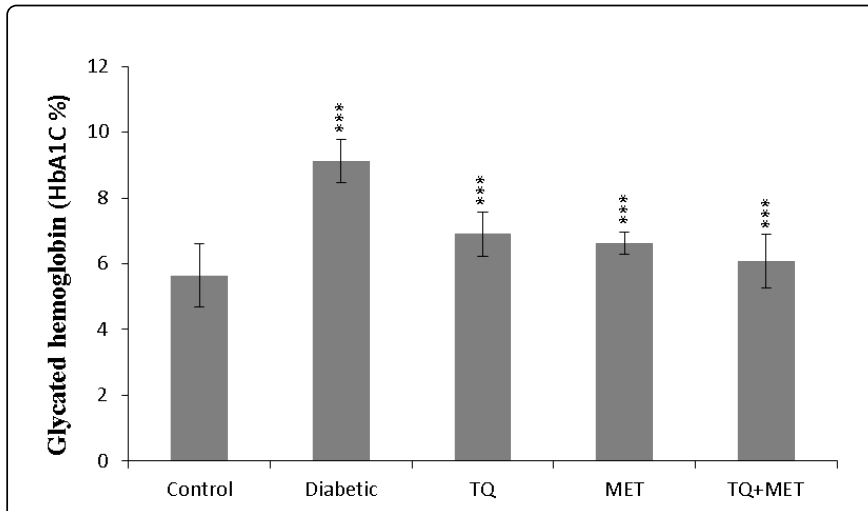

Figure 3: Effect of TQ and/or MET on $\mathrm{HbA1C} \%$ level. Data are presented as mean \pm standard deviation. Significantly ${ }^{* *} \mathrm{P}<0.001$ different from the diabetic control. HbA1C\%: glycated hemoglobin percent.

\section{Effect of TQ and MET on MDA level}

Results in Figure 4 revealed that the mean values of MDA level in the diabetic group were significantly $(\mathrm{P}<0.001)$ increased roughly 4 folds compared with those of the negative control group in both liver and pancreas homogenates. As a result of treating diabetic rats with either TQ or MET; the mean values of MDA in liver and pancreas homogenates were significantly decreased compared to diabetic group. 
Citation: El-Aarag B, Hussein W, Ibrahim W, Zahran M (2017) Thymoquinone Improves Anti-Diabetic Activity of Metformin in StreptozotocinInduced Diabetic Male Rats. J Diabetes Metab 8: 780. doi:10.4172/2155-6156.1000780

Page 4 of 8

Remarkably, the combined effect of TQ plus MET showed the highest decline level of lipid peroxidation in two homogenates compared to TQ or MET group.

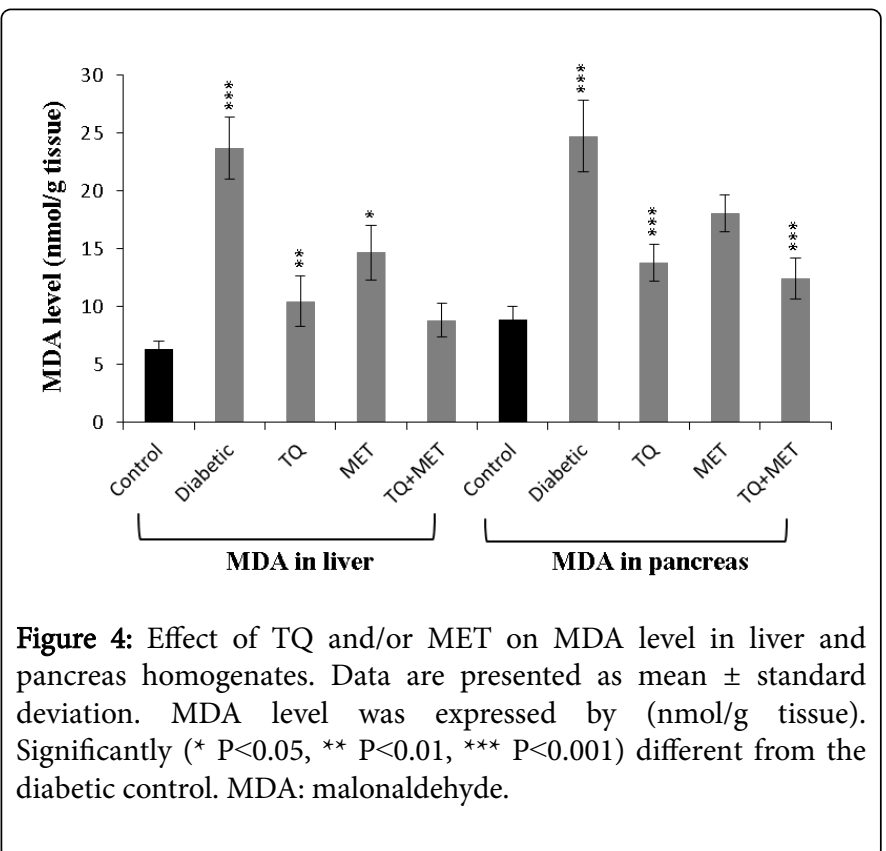

\section{Effect of TQ and MET on TAC level}

As shown in Figure 5, the TAC level in the diabetic group were significantly $(\mathrm{P}<0.001)$ diminished due to the effect of STZ in both homogenates, compared to the corresponding normal control. However, the combined treatment with TQ and MET exhibited significant effect on TAC level in both homogenates compared to the individual effect of TQ or MET. As the TAC level in liver and pancreas homogenates were not only restored to normal values but also increased to 1.5- and 2-fold, respectively than that of normal group.

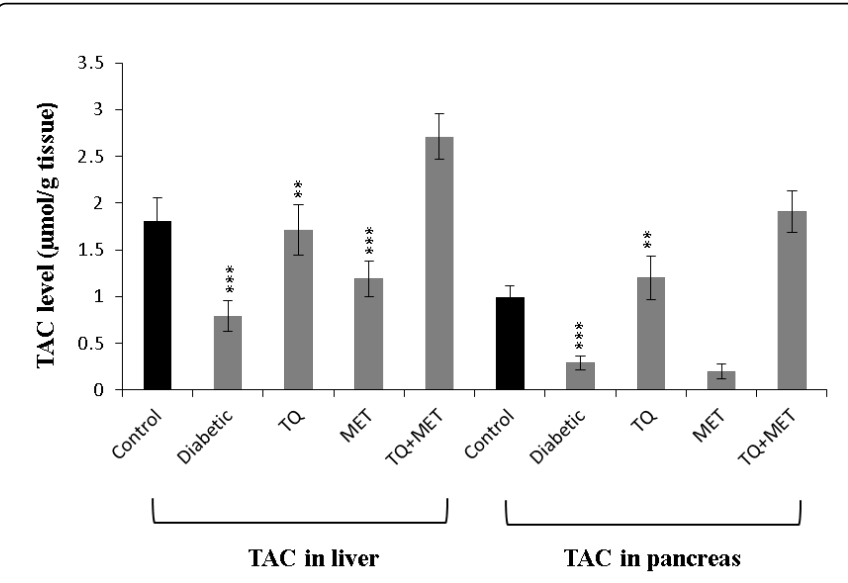

Figure 5: Effect of TQ and/or MET on TAC level in liver and pancreas homogenates. Data are presented as mean \pm standard deviation. TAC level was expressed by $(\mu \mathrm{mol} / \mathrm{g}$ tissue). Significantly $\left.{ }^{* *} \mathrm{P}<0.01,{ }^{* * *} \mathrm{P}<0.001\right)$ different from the diabetic control. TAC: total antioxidant capacity.

\section{Effect of TQ and MET on Glut-2 mRNA expression level}

Comparing with normal rats, STZ-induced diabetes was found to significantly $(\mathrm{P}<0.01)$ suppress Glut-2 mRNA expression in liver tissues as shown in Figure 6. In TQ group, a significant $(\mathrm{P}<0.05)$ elevation in Glut-2 expression was noticed compared with the diabetic group and the observed value was 0.24. Also, the administration of MET in diabetic rats increased Glut-2 expression to 0.43 . Conversely, diabetic rats treated with both TQ and MET for 7 weeks showed the highest elevation in Glut-2 mRNA expression and the detected value was 0.77 .

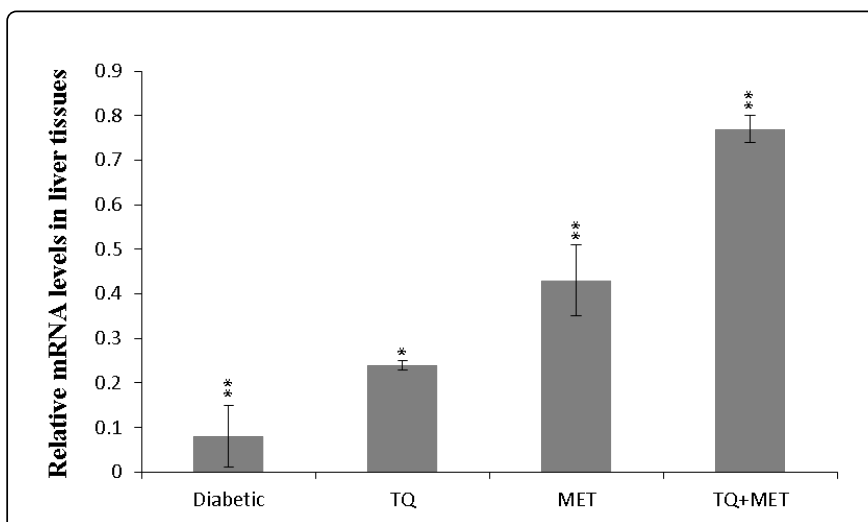

Figure 6: Effect of TQ and/or MET on Glut-2 mRNA expression in liver tissues. Data are presented as mean \pm standard deviation. Glut-2 mRNA expression was related to $\beta$-actin. Significantly $\left({ }^{*} \mathrm{P}<0.05,{ }^{*} \mathrm{P}<0.01\right)$ different from the diabetic control. Glut-2: glucose transporter- 2 .

\section{Effect of TQ and MET on insulin receptor labeling index percentage}

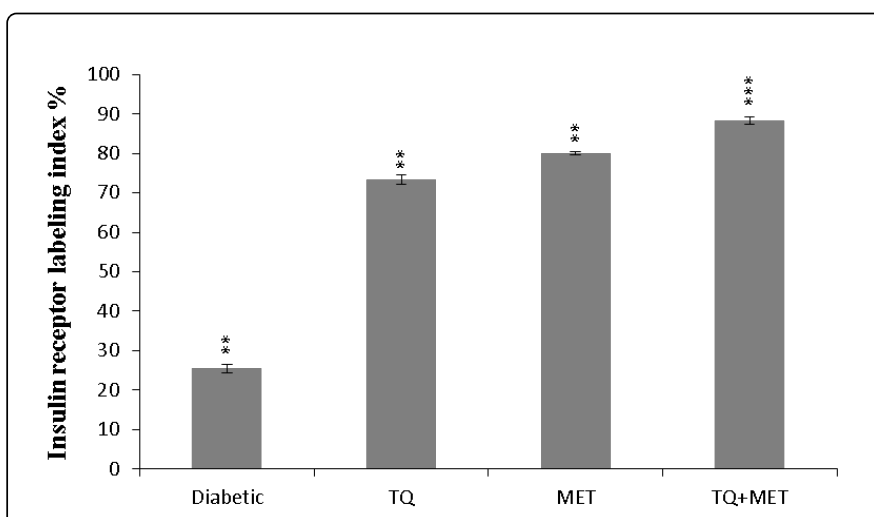

Figure 7: Effect of TQ and/or MET on insulin receptor in liver tissues, as determined by immunohistochemistry assay. Insulin receptor was expressed as labeling index percentage. Data are presented as mean \pm standard deviation. Significantly $\left({ }^{* *} \mathrm{P}<0.01\right.$, $\left.{ }_{\star * *} \mathrm{P}<0.001\right)$ different from the diabetic control.

Insulin receptor in liver tissues of diabetic rats was detected using immunohistochemistry assay and measured as labeling index percentage. As displayed in Figure 7, in comparison with non-diabetic group, insulin receptor was significantly $(\mathrm{P}<0.01)$ declined in liver tissues of diabetic rats, the detected value was $25.5 \%$. Treating diabetic 
rats with TQ or MET significantly $(\mathrm{P}<0.01)$ increased the percentage by 73.35 or 80 , respectively. However, insulin receptor levels were significantly $(\mathrm{P}<0.001)$ augmented by $88.2 \%$ after the treatment with both TQ and MET.

\section{Discussion}

$\mathrm{DM}$ is a multi-factorial illness described by hyperglycemia, lipoprotein abnormalities and altered intermediary metabolism of nutrients associated with deficiencies in insulin secretion and/or resistance to its action. Therefore, the present study aimed to assess the anti-diabetic effect of combined oral administration of both TQ and MET against STZ-induced diabetic rats.

The metabolic disorder of diabetes is frequently diagnosed by hyperglycemia which occurs when cells become unable to utile glucose and/or the liver and skeletal muscles can't store glycogen [32]. This is obviously noticed in Figure 1 which showed that diabetic rats possess significantly increased blood glucose level, compared to normal control. But, the combined treatment with TQ and MET markedly reduced and normalized the elevation of glucose level. This might be related to the effect of TQ causing partial regeneration and proliferation of pancreatic $\beta$-cells leading to increase in insulin secretion [33]. Also, it supports the utilization of glucose by cells in glycolysis and Kreb's cycle pathways [34]. Additionally, TQ possessed effect in decreasing liver glucose production via gluconeogenesis [35] and decreasing intestinal glucose absorption [36]. Furthermore, the anti-hyperglycemic effect of TQ due to reduction of oxidative stress preserving pancreatic $\beta$-cell integrity and leading to insulin levels increase [37]. Moreover, the anti-hyperglycemic effect of metformin might be linked to improving peripheral sensitivity to insulin, inhibiting gastrointestinal absorption of glucose [38], or decreasing hepatic glucose production [39].

The levels of cholesterol and triglycerides of the positive control group were significantly increased compared with those of the negative control group. These results were concomitance with the previously mentioned that diabetes was associated with an increasing in the synthesis of cholesterol, which may be due to the increased activity of 3-hydroxy-3-methylglutaryl-coenzyme A reductase (HMG CoA R) [40]. On the other hand, treating the diabetic rats with either TQ or MET significantly decreased the level of serum cholesterol and triglycerides. Remarkably, the level of serum triglycerides and cholesterol was reduced and corrected to the normal values after the treating with TQ and MET. It was stated that plasma triglyceride and cholesterol levels diminished in the diabetic rats treated with TQ [41] due to its anti-oxidant activity [42]. Also, the anti-lipidemic action of TQ may be caused by its ability to stimulate insulin secretion and action. In addition, TQ generated a hypocholesterolemic effect in diabetic rats through regulation of cholesterol via up-regulation of hepatic LDL receptor gene and suppressing the HMG-CoA R gene [41].

The energy lost from the body in DM may be replaced through the degeneration of the adipocytes and muscle tissues which will lead to loss in body weight. This finding was agreed with our result in Figure 2 where STZ-induced diabetes caused a significant loss in BWG in rats after consecutive 7 weeks. On the other hand, the treated diabetic rats with TQ or MET reduced the loss in the BWG, however, the combined treatment showed the highest improvement in the loss of BWG. These findings are in agreement with the previously stated that the improvement of the body weight in diabetic rats may be due to the improved glycemic control [43]. Also, it has been reported that MET reduces hyperglycemia and protein wasting due to carbohydrate inaccessibility [44]. Consequently, the maximum effect of TQ plus MET to reduce the loss in body weight might be related to their hypoglycemic activity.

During diabetes the excess of glucose present in blood reacts with hemoglobin to form HbA1c [45]. It is widely accepted as a single most reliable indicator of metabolic control in diabetes mellitus. Data in Figure 3 demonstrated that the level of $\mathrm{HbA1c} \%$ was elevated in STZdiabetic rats, compared to the corresponding normal rats. Our result was in agreement with the previously reported which stated that plasma HbAlc levels were higher in diabetic rats than in normal groups [46]. The observed increase in the levels of $\mathrm{HbAlc} \%$ in diabetic control group rats is due to the presence of excessive amounts of blood glucose.

Conversely, TQ or MET decreased the level of HbAlc\%, however, the maximum reduction was noticed after the treatment with TQ and MET. Glycated protein concentration reflects an average of blood glucose level over a period time; their determination provides a reliable means of monitoring diabetic control $[47,48]$ Therefore, the ability of combination given of TQ and MET to decline the elevated level of $\mathrm{HbA} 1 \mathrm{c} \%$ might be related to their hypoglycemic effects.

There is a close relationship between the increase of free radicals, blood glucose, and lipid peroxidation in the progress of diabetes [49]. Diabetics usually exhibit high oxidative stress due to persistent and chronic hyperglycemia, which thereby depletes the activity of antioxidative defense system and thus promotes free radicals generation [50]. Oxygen free radicals could react with polyunsaturated fatty acids which lead to lipid peroxidation [51]. In our investigation STZ-diabetic rats showed approximately 4 -folds increasing in lipid peroxidation level (Figure 4) accompanied by decreasing in TAC level in the liver and pancreas homogenates compared with their corresponding values in negative control group (Figure 5).

These results are in agreement with previous investigations [52-53] and may be attributed to the fact that the elevated generation of free radicals resulting in the consumption of anti-oxidant defense components which may lead to disruption of cellular functions and oxidative damage to membranes and may enhance susceptibility to lipid peroxidation $[54,55]$. On the other hand, the combined treatment with TQ and MET improved MDA and TAC and closely restored them to their normal levels. This result may be attributed to anti-oxidant activity of TQ and its scavenging effect on the free radicals [56]. Besides, it triggers the oxidative stress resistance by reducing the elevated levels of MDA [57].

Glut-2 is a carrier protein that facilitates glucose movement across cell membranes. It is the main transporter for transfer of glucose between liver and blood and for glucose reabsorption from kidneys [58]. The current result revealed significant down-regulation in the expression level of the Glut-2 mRNA in liver of diabetic rats, compared to non-diabetic control groups (Figure 6). This result agree with previously stated that the decreased expression of Glut-2 is reversible and depends on the diabetic environment as well as diabetes induced decreasing in expression of Glut-2 [59]. In contrast, rats treated by TQ or MET indicated significant up-regulation in Glut-2 expression level compared to the diabetic control group, however, the highest significant up-regulation was detected in rat treated with TQ and MET together. 
It has been reported that Glut-2 deficiency in mice results in hyperglycemia [60]. Additionally, drugs enable Glut-2 translocation and improve insulin sensitivity could be useful for the treatment of diabetes [61,62]. Also, MET declined blood glucose concentrations by increasing glucose disposal in skeletal muscle, as well as, AMPactivated protein kinase (AMPK) stimulated glucose uptake into skeletal muscle and the inhibition of liver gluconeogenesis. Furthermore, it has been reported that MET could activate AMPK in rat hepatocytes [63]. Moreover, studies revealed that nigella sativa exhibited a remarkable ability to stimulate glucose uptake in skeletal muscle [64]. Therefore, the maximum dual effect of TQ and MET to regulated the decreased expression of Glut- 2 could be related to their hypoglycemic effect which lead to the improvement in level of Glut-2 mRNA expression.

Insulin receptor is a transmembrane receptor, which belongs to the large class of tyrosine kinase receptors, and activated by insulin [65]. It acts mainly to mediate the metabolic actions of insulin [66]. Our results in Figure 7 clarified that STZ-induced diabetic rats exhibited significant reduction in insulin receptor. This finding is compatible with the previous study revealed that in diabetes; the insulin resistance is partly mediated by reducing level of insulin receptor expression [67]. Also, it was reported that a decline in insulin receptor signaling leads to type $2 \mathrm{DM}[68]$.

Alternatively, treating diabetic rats either with TQ or MET significantly improved and increased the insulin receptor expression. However, the maximum elevation level of insulin receptor was noticed in diabetic rats treated with both TQ plus MET. Our result is being supported by a report indicating that MET increases insulin receptor activation in human liver [69]. Additionally, MET can improve insulin sensitivity via its effects on insulin receptor signaling pathways of insulin action [70]. Moreover, the administration of nigella sativa significantly induced the IR gene expression of diabetic rats [71].

\section{Conclusion}

Our results indicated that TQ can be a useful supplementary agent to enhance anti-diabetic effect of MET in male rats by inhibiting diabetic complications such as hyperglycemia and oxidative damage. Besides, it up-regulates Glut-2 and insulin receptor in hepatocytes. Consequently, TQ can be used as an add therapy to conventional diabetic drugs.

\section{Conflict of Interest}

The authors have declared that there is no conflict of interests.

\section{Acknowledgements}

We would like to acknowledge Technology Innovation Agency for funding and the Biomedical Resource Unit personnel for their technical assistance.

\section{References}

1. Vlad I, Popa AR (2012) Epidemiology of diabetes mellitus: a current review. Romanian J Diabetes Nutr Metab Dis 19: 433-440.

2. WHO (2013) Diabetes. Fact sheet $\mathrm{N}^{\circ} 312$ World Health Organization.

3. Cnop M, Welsh N, Jonas JC, Jörns A, Lenzen S, et al. (2005) Mechanisms of pancreatic beta-cell death in type 1 and type 2 diabetes: many differences, few similarities. Diabetes 54: S97-107.

4. Mabed M, Shahin M (2012) Mesenchymal stem cell-based therapy for the treatment of type 1 diabetes mellitus. Curr Stem Cell Res Ther 7: 179-190.
5. $\mathrm{ADA}$ (2014) Diabetes Basics. Facts About Type 2.

6. International Diabetes Federation (2016) IDF Diabetes Atlas (7thedn).

7. Shaw JE, Sicree RA, Zimmet PZ (2010) Global Estimates of the Prevalence of Diabetes for 2010 and 2030. Diabetes Res Clin Pract 87: 4-14.

8. Groot M, Anderson R, Freedland KE, Clouse RE, Lustman PJ (2001) Association of depression and diabetes complications: a metaanalysis. Psychosom Med 63: 619-630.

9. Jacobson AM (2004) Impact of improved glycemic control on quality of life in patients with diabetes. Endocr Pract 10: 502-508.

10. Stratton IM, Adler AI, Neil HAW, Matthews DR, Manley SE (2000) Association of glycaemia with macrovascular and microvascular complications of type 2 diabetes (UKPDS 35): Prospective observational study. Brit Med J 321: 405-412.

11. Rendell M (2004) Advances in diabetes for the millennium: Drug therapy of type 2 diabetes. Med Gen Med 6: 9.

12. Rotella CM, Monami M, Mannucci E (2006) Metformin beyond diabetes: New life for an old drug. Current Diabetes Rev 2: 307-315.

13. Foretz M, Hébrard S, Leclerc J, Zarrinpashneh E, Soty M, et al. (2010) Metformin inhibits hepatic gluconeogenesis in mice independently of the LKB1/AMPK pathway via a decrease in hepatic energy state. J Clin Invest 120: 2355-2369.

14. Mathur ML, Gaur J, Sharma R, Haldiya KR (2011) Antidiabetic properties of a spice plant Nigella sativa. J Endocrino \& Metabolism 1: 1-8.

15. Khader M, Eckl PM (2014) Thymoquinone: an emerging natural drug with a wide range of medical applications. Iran J Basic Med Sci 7: 950-957.

16. Ahmad A, Husain A, Mujeeb M, Khan SA, Najmi AK (2013) A review on therapeutic potential of Nigella sativa: A miracle herb. Asian Pacific J Tropical Biomed 3: 337-352.

17. Ali BH, Blunden G (2003) Pharmacological and toxicological properties of Nigella sativa. Phytother Res 17: 299-305.

18. Ghosheh OA, Houdi AA, Crooks PA (1999) High performance liquid chromatographic analysis of the pharmacologically active quinones and related compounds in the oil of the black seed (Nigella sativa). J Pharm Biomed Anal 19: 757-762.

19. Pari L, Srinivasan S, Saddiq M (2010) Preventive effect of diosmin, a bioflavonoid, on glycoprotein changes in streptozotocin-nicotinamideinduced type 2 diabetic rats. Int J Pharma Sci Res 1: 89-95.

20. Al-Logmani A, Zari TA (2011) Long-term effects of Nigella sativa L. oil on some physiological in normal and streptozotocin-induced diabetic rats. J Diabetes Mellitus 1: 46-53.

21. El-Dakhakhny M, Madi NJ, Lembert N (2002) Ammon HP Nigella sativa oil, nigellone and derived thymoquinone inhibit synthesis of 5lipoxygenase products in polymorphonuclear leukocytes from rats. J Ethnopharmacol 81: 161-164.

22. El Rabey HA, Al-Seeni MN, Bakhashwain AS (2017) The Antidiabetic Activity of Nigella sativa and Propolis on Streptozotocin-Induced Diabetes and Diabetic Nephropathy in Male Rats. Evid Based Complement Alternat Med 2017: 1-14.

23. Barham D, Trinder P (1972) An improved colour reagent for the determination of blood glucose by the oxidase system. The Analyst 97: 142-145.

24. Allain CC, Poon LS, Chan CS, Richmond W, Fu PC (1974) Enzymatic determination of total serum cholesterol. Clin Chem 4: 470-475.

25. Foster JB, Dunn RT (1973) Stable reagents for determination of serum triglyceride by colorimetric condensation method. Clin Chim Acta 19: 338-340.

26. Nayak SS, Pattabiraman TN (1981) A new colorimetric method for the estimation of glycosylated hemoglobin. Clin Chim Acta 109: 267-274.

27. Ohkawa H, Ohishi N, Yagi K (1979) Assay for lipid peroxides in animal tissues by thiobarbituric acid reaction. Anal Biochem 95: 351-358.

28. Benzie IF, Strain JJ (1999) Ferric reducing/antioxidant power assay: direct measure of total antioxidant activity of biological fluids and modified 
version for simultaneous measurement of total antioxidant power and ascorbic acid concentration. Methods Enzymol 299: 15-27.

29. El-Aarag BYA, Kasai T, Zahran MAH, Zakhary NI, Shigehiro T, et al. (2014) In vitro anti-proliferative and anti-angiogenic activities of thalidomide dithiocarbamate analogs. Int Immunopharmacol 21: 283-292.

30. Chen J, Stavro PM, Thompson LU (2002) Dietary Flaxseed Inhibits Human Breast Cancer Growth and Metastasis and Downregulates Expression of Insulin-Like Growth Factor and Epidermal Growth Factor Receptor. Nutrition \& Cancer 43: 187-192.

31. Goldstein DE (1995) How much do you know about glycated hemoglobin testing. Clin Diabetes 13: 60-63.

32. Luis-Rodríguez D, Martínez-Castelao A, Górriz JL, De-Álvaro F, Navarro-González JF (2012) pathophysiological role and therapeutic implications of inflammation in diabetic nephropathy. $\mathrm{W} J$ diabetes 3 : 7-18.

33. Mansi KM (2005) Effects of oral administration of water extract of Nigella sativa on serum concentrations of insulin and testosterone in alloxan induced diabetic rats. Pak J Biolo Sci 8: 1152-1156.

34. Krishnamurthy B, Chee J, Jhala G, Fynch S, Graham KL (2012) Complete diabetes protection despite delayed thymic tolerance in NOD8.3 TCR transgenic mice due to antigen-induced extrathymic deletion of T Cells. Diabetes 61: 425-435.

35. Fararh KM, Atoji Y, Shimizu Y, Takewaki T (2002) Isulinotropic properties of Nigella sativa oil in Streptozotocin plus Nicotinamide diabetic hamster. Res Vet Sci 73: 279-282.

36. Meddah B, Ducroc R, El-Abbes Faouzi M, Eto B, Mahraoui L (2009) Nigella sativa inhibits intestinal glucose absorption and improves glucose tolerance in rats. J Ethnopharmacol 121: 419-424.

37. Abdelmeguid NE, Fakhoury R, Kamal SM, Al wafai RJ (2010) Effects of Nigella sativa and thymoquinone on biochemical and subcellular changes in pancreatic $\beta$-cells of streptozotocin-induced diabetic rats. J Diabetes 2 : 256-266.

38. Nathan DM, Holman RR, Buse JB (2008) Management of hyperglycemia in type 2 diabetes: a consensus algorithm for the initiation and adjustment of therapy. Diabetes Care 31: 173-175.

39. Fulgencio JP, Kohl C, Girard J, Pégorier JP (2001) Effect of metformin on fatty acid and glucose metabolism in freshly isolated hepatocytes and on specific gene expression in cultured hepatocytes. Biochem Pharmacol 62: 439-46.

40. Ravi K, Rajasekaran S, Subramanian S (2005) Antihyperlipidemic effect of Eugenia jambolana seed kernel on streptozotocin-induced diabetes in rats. Food Chem Toxicol 43: 1433-1439.

41. Al-Naqeep G, Ismail M, Allaudin Z (2009) Regulation of low-density lipoprotein receptor and 3-hydroxy-3-methylglutaryl coenzyme A reductase gene expression by thymoquinone-rich fraction and thymoquinone in HepG2 cells. J Nutrigenet Nutrigenomics 2: 163-172.

42. Darakhshan S, Pour AB, Colagar AH, Sisakhtnezhad S (2015) Pharmacological Research Thymoquinone and its therapeutic potentials. Pharmacol Res 95-96: 138-158.

43. Shirwaikar A, Rajendran K, kumar DC (2004) Oral antidiabetic activity of Annona squamosa leaf alcohol extract in NIDDM rats. Pharm Biol 42: 30-35.

44. Kanter M, Coskun O, Korkmaz A, Oter S (2004) Effects of Nigella sativa on oxidative stress and b-cell damage in streptozocin-induced diabetic rats. Anatomical Record 279: 685-691.

45. Sheela GC, Augusti KT (1992) antidiabetic effects of S-allyl cystine sulfoxide isolated from garlic Allium sativum Linn. Indian J Exp Biol 30: 523-526.

46. Cintra LTA, Samuel RO, Facundo ACS, Prieto AKC, Sumida DH, et al. (2014) Relationships between oral infections and blood glucose concentrations or $\mathrm{HbAlc}$ levels in normal and diabetic rats. Int Endodontic J 47: 228-237.
47. Hill RP (1990) Semi-automated colorimetric method for measuring Glycated hemoglobin with reduction of NBT evaluated. Clin Chem 36: 2131-2133.

48. Somani BL, Sinha R, Gupta M (1989) Fructosamine assay modified for the estimation of glycated hemoglobin. Clin Chem 35: 497-497.

49. Reddy SV, Tiwari AK, Kumar US, Rao RJ, Rao JM (2005) Free radical scavenging, enzyme inhibitory constituents from antidiabetic Ayurvedic medicinal plant Hydnocarpus wightiana Blume. Phytother Res 19: 277-281.

50. Kamalakannan N, Prince PSM (2006) Antihyperglycaemic and antioxidant effect of rutin, a polyphenolic flavonoid, in streptozotocininduced diabetic Wistar rats. Basic Clin Pharmacol Toxicol 98: 97-103.

51. Karthikesan K, Pari L, Menon VP (2010) Combined treatment of tetrahydro-curcumin and chlorogenic acid exerts potential antihyperglycemic effect on streptozotocin-nicotinamide-induced diabetic rats. Gen Physiol Bio-physics 29: 23-30.

52. Al-Malki AL, El Rabey HA (2015) The antidiabetic effect of low doses of moringa oleifera lam. Seeds on streptozotocin induced diabetes and diabetic nephropathy in male rats. BioMed Rese Int pp: 1-13.

53. Al-Malki AL (2013) Oat attenuation of hyperglycemia-induced retinal oxidative stress and NF-B activation in streptozotocin-induced diabetic rats. Evid based Complement Alternat Med 2013: 1-8.

54. Gomathi D, Kalaiselvi M, Ravikumar G, Devaki K, Uma C (2014) Evaluation of antioxidants in the kidney of streptozotocin induced diabetic rats. Indian J Clin Biochem 29: 221-226.

55. Suryanarayana P, Satyanarayana A, Balakrishna N, Kumar PU, Bhanuprakash G (2007) Effect of turmeric and curcumin on oxidative stress and antioxidant enzymes in streptozotocin-induced diabetic rat. Med Sci Monit 13: 286-292.

56. Burits M, Bucar F (2000) Antioxidant activity of Nigella sativa essential oil. Phytother Res 14: 323-328.

57. Al-Majed AA, Al-Omar FA, Nagi MN (2006) Neuroprotective effects of thymoquinone against transient forebrain Ischemia in the rat hippocampus. Eur J Pharmacol 543: 40-47.

58. Freitas HS, Schaan BD, Seraphim PM, Nunes MT, ZMachado UF (2005) Acute and short-term insulin induced molecular adaptations of GLUT2 gene expression in the renal cortex of diabetic rats. Mol Cell Endocrinol 237: 49-57.

59. Thorens B, Wu YJ, Leahy JL, Weir GC (1992) The Loss of GLUT2 Expression by Glucose-unresponsive Cells of $\mathrm{db} / \mathrm{db}$ Mice Is Reversible and Is Induced by the Diabetic. Environment 90: 77-85.

60. Augustin R (2010) The Protein Family of Glucose Transport Facilitators: It's Not Only About Glucose After All. Life 62: 315-333.

61. Kipmen-Korgun D, Bilmen-Sarikcioglu S, Altunbas H, Demir R, Korgun E (2009) Type-2 diabetes down-regulates glucose transporter proteins and genes of the human blood leukocytes. Scand J Clin Lab Invest 69: 350-358.

62. Shepherd PR, Kahn BB (1999) Glucose transporters and insulin action implications for insulin resistance and diabetes mellitus. N Engl J Med 341: 248-257.

63. Musi N, Hirshman MF, Nygren J, Svanfeldt M, Bavenholm P, et al. (2002) Metformin increases AMP-activated protein kinase activity in skeletal muscle of subjects with type 2 diabetes. Diabetes 51(7): 2074-2081.

64. Benhaddou-Andaloussi A, Martineau LC, Spoor D, Vuong T, Leduc C, et al. (2008) Antidiabetic activity of Nigella sativa seed extract in cultured pancreatic $\beta$-cells, skeletal muscle cells, and adipocytes. Pharm Biol 46: 96-104.

65. Ward CW, Lawrence MC (2009) Ligand-induced activation of the insulin receptor: a multi-step process involving structural changes in both the ligand and the receptor. Bioassays 31: 422-434.

66. Accili D, Drago J, Lee EJ, Johnson MD, Cool MH, et al. (1996) Early neonatal death in mice homozygous for a null allele of the insulin receptor gene. Nat Genet 12: 106-109. 
Citation: El-Aarag B, Hussein W, Ibrahim W, Zahran M (2017) Thymoquinone Improves Anti-Diabetic Activity of Metformin in StreptozotocinInduced Diabetic Male Rats. J Diabetes Metab 8: 780. doi:10.4172/2155-6156.1000780

Page 8 of 8

67. Virkamäki A, Ueki K, Kahn CR (1999) Protein-protein interaction in insulin signaling and the molecular mechanisms of insulin resistance. J Clin Invest 103: 931-943.

68. Xavier S, Sadanandan J, George N, Paulose CS (2012) $\beta 2$-Adrenoceptor and insulin receptor expression in the skeletal muscle of streptozotocin induced diabetic rats: Antagonism by vitamin D3 and Curcumin. Eur J Pharmacol 687: 14-20.

69. Gunton JE, Delhanty PJ, Takahashi S, Baxter RC (2003) Metformin Rapidly Increases Insulin Receptor Activation in Human Liver and
Signals Preferentially through Insulin-Receptor Substrate-2. J Clin Endocrinol Metab 88: 1323-1332.

70. Tahrani AA, Barnett AH, Bailey CJ (2016) Pharmacology and therapeutic implications of current drugs for type 2 diabetes mellitus. Nat Rev Endocrinol 12: 566-592.

71. Balbaa M, El-Zeftawy M, Ghareeb D, Taha N, Mandour A (2016) Nigella sativa Relieves the Altered Insulin Receptor Signaling in StreptozotocinInduced Diabetic Rats Fed with a High-Fat Diet. Oxid Med Cell Longev 2016: 1-16. 